\title{
VREDNOTE, VREDNOSTI IN RAZVOJNI POTENCIALI OBMOČIJ VAROVANJA
}

\author{
Barbara Lampič, ${ }^{*}$ Irena Mrak** \\ Univerza v Ljubljani, Filozofska fakulteta, Oddelek za geografijo, Aškerčeva 2, \\ SI- 1000 Ljubljana, Slovenja. \\ *e-mail: barbara.lampic@ff.uni-lj.si, **e-mail: irena.mrak@siol.net
}

Izvirni znanstveni članek

COBISS 1.01

\section{Izvleček}

Prepoznavanje območij varovanja in njihovih vrednot ter ustrezna opredelitev njihove vrednosti lahko pomembno prispevajo k trajnostnemu regionalnemu razvoju. Območja varovanja z razvojnega vidika združujejo okoljske, kulturne, socialne in človeške potenciale, ki imajo v skladu z načinom varovanja določeno neposredno oziroma posredno uporabno vrednost in tudi vrednost neuporabe. Ta območja je potrebno razumeti ne le kot območja varovanja ampak kot območja velikih, v Sloveniji pretežno neprepoznanih in razvojno slabo aktiviranih potencialov.

Ključne besede: območja varovanja, varstvo narave, vrednote in vrednosti prostora, razvojni potenciali, regionalni razvoj, trajnostni razvoj, Slovenija

\section{VALUABLES, VALUES AND DEVELOPMENT POTENTIALS OF PROTECTED AREAS}

\begin{abstract}
Recognition of protected areas and their valuables well as the appropriate definition of values in these areas can importantly contribute to sustainable regional development. From the development point of view the protected areas incorporate environmental, cultural, social and human potentials which, according to the protection mode, have certain direct and/or indirect applied value as well as the value of "unused". Protected areas should be understood not only as areas of protection but also as areas of great and in Slovenia not yet recognized and poorly used potentials.
\end{abstract}

Key words: protected areas, nature protection, spatial valuables, spatial values, development potentials, regional development, sustainable development, Slovenia 


\section{UVOD}

Zavarovana in varovana območja združujejo vse temeljne vrednote prostora: okoljske, ekonomske, kulturne oz. družbene. Njihova izjemnost, tipičnost in v nekaterih primerih tudi ogroženost pa so botrovale $\mathrm{k}$ temu, da so bila določena območja oziroma posamezne naravne ali kulturne prvine tudi zavarovane ali opredeljene kot posebna varstvena območja.

Dejansko gre torej za posebej dragocena, vredna območja, ki imajo poleg načelne vrednosti tudi pomemben ekonomski, okoljski in družbeni potencial, kar je ključnega pomena za trajnosten razvoj tako regije kot celotne države.

Razmere v slovenskem prostoru kažejo precej drugačno sliko: v praksi se varovanje povsem ločuje od razvoja in zavarovanje v Sloveniji predstavlja razvojno oviro, ki jo kot tako najbolj in najprej občutijo že na lokalnem, občinskem nivoju. Od tod izvirajo številna nesoglasja, nasprotovanja in neuspešni poskusi razvojnega aktiviranja območij varovanja, saj so pojmi kot so razvoj, regionalni razvoj, prostorski razvoj ipd. pri nas interpretirani izrazito kvantitativno. Kvalitetno okolje/prostor, trajnostni prostorski razvoj, izjemna kulturna pokrajina v Sloveniji žal niso prepoznani kot vrednota. Ozko razmišljanje o prostoru, njegovih vrednotah in vrednostih, je pogosto prisotno na vseh nivojih; pri pobudnikih in nosilcih idej, pripravljavcih prostorskih aktov, nosilcih urejanja prostora in prostorskih sprememb, prostorskih načrtovalcih, investitorjih in nenazadnje tudi prebivalcih, ki sooblikujemo podobo pokrajine. Omenjena problematika je prisotna v širšem slovenskem prostoru, še posebej pa je pereča in občutljiva prav na območjih varovanja.

Številni avtorji so glede na izhodišča in problematiko različno opredeljevali naravne vrednote. Vrednote so vse tisto, čemur priznavamo veliko načelno vrednost in posledično tudi določeno prednost, po Kirnu (1994) in Curry-ju (2006) pa naravnim razmeram določene vrednosti lahko dodeli šele človek. Na naše ravnanje $\mathrm{z}$ okoljem, naravo in naravnimi viri vpliva okoljska zavest in vzpostavljen sistem vrednot - katere vrednote vidimo, prepoznamo v naravi oziroma širše, v okolju. Vpliv okoljske zavesti in njenih vrednot je navzoč povsod, posredno pa se odraža v najrazličnejših oblikah človekovih dejavnostih v okolju (Kirn, 2004).

Zavedanje heterogenih in med seboj povezanih vrednosti naravnega in družbenega okolja zavarovanih območij se tako odraža tudi pri vrednotenju naravnega in kulturnega kapitala. Uporabljena delitev na intrinzične in instrumentalne vrednote je splošna in širše uporabna. Med instrumentalne vrednote uvrščamo kulturne, estetske, funkcijske, raziskovalne in izobraževalne ter ekonomske, medtem ko intrinzične predstavljajo vrednoto same po sebi in ne zaradi svoje neposredne uporabne vrednosti (Gray, 2004). Šele ko imamo vzpostavljen sistem vrednot (o prostoru in njegovih posameznih sestavinah), ko jih prepoznamo v našem vsakdanjem življenju in postanejo del naše identitete, lahko govorimo o ustreznem »okolju« za razumevanje in razvoj kapitalov; okoljskega, kulturnega, socialnega in gospodarskega.

Naravni kapital lahko pojmujemo kot zaloge, vire in rezerve. Zaloga postane vir, ko je uporabna za zadovoljevanje določenih prepoznanih potreb ljudi (npr. hrana, zavetje, toplota, transport). Transformacija iz zaloge v vir je reverzibilna in odvisna od človekove razvojne stopnje in znanja, $\mathrm{v}$ primeru reverzibilnosti pa viri lahko postanejo rezerva - to pomeni, da jih imamo $\mathrm{v}$ rezervi in lahko ob določeni dejavnosti ponovno postanejo vir. Naravne vire 
najpogosteje delimo na neobnovljive (kapitali ali zaloge: npr. fosilna goriva, rude), obnovljive (pretok in prihodek: direktna in indirektna sončna energija, geotermalna energija) in ostale, kar vključuje npr. izgled pokrajine. Zavarovanje naravnih virov lahko pomeni, da $\mathrm{z}$ omejevanjem ali celo prepovedjo rabe določene naravne vire, ki bi jih sedanja generacija izrabila, želimo ohraniti za prihodnje generacije. Na ta način spodbudimo rabo drugih virov (Hagget, 2001). Od splošno vzpostavljenega sistema vrednot pa je odvisno, kakšno bo razmerje med ekonomskim učinkom in načinom rabe naravnih virov.

$\mathrm{Z}$ vidika regionalnega razvoja je najbolje uporabiti ekonomsko opredelitev vrednot prostora. $\mathrm{V}$ dosedanjem razvoju so bile $\mathrm{v}$ ospredju vedno tiste vrste kapitalov, ki so imele povsem neposredno uporabno vrednost kot npr. surovine (rude, les), v veliki meri prezrte pa so bile vrste kapitalov s posredno uporabno vrednostjo in pa t.im. kapitali z vrednostjo neuporabe. V to skupino sodi doslej zelo skromno uporabljen okoljski kapital z razvojno neaktiviranimi naravnimi viri in ekosistemskimi storitvami. O družbeni vrednosti biotske raznovrstnosti kot enega ključnih kapitalov območij varovanja do sedaj predvsem na konkretnih zavarovanih območjih nismo razmišljali in še manj izvajali ustrezne študije, sistematično pa sta to vsebino iz ekonomske perspektive predstavili Hladova in Slabe Erkerjeva (2004). Izhodišče njunega prispevka je, da je prav biotska raznovrstnost najpomembnejše naravno bogastvo zavarovanih območij in tudi eno najpomembnejših v Sloveniji ter da predstavlja ekonomsko razvojno priložnost, ki pa je bila do sedaj povsem prezrta. Kljub dejstvu, da je bila že v Strategiji gospodarskega razvoja Slovenije (2001) poudarjena potreba po razumevanju okolja kot razvojnega dejavnika, pa je pojmovanje zavarovanih območij kot razvojnih območij pri nas tuje in v praksi navadno prihaja do strogega ločevanja varstva oz. varovanja od razvoja. Med obstoječimi območji varovanja se kot prednosti na okoljskem, socialnem in ekonomskem polju najpogosteje izpostavljajo naslednji potenciali:

- Okoljski potenciali; biotska raznovrstnost, prostor - pokrajina, ekosistemske storitve;

- Socialni potenciali; socialna vključenost, zdravje, izobrazba;

- $\quad$ Ekonomski potenciali; zaposlitev in dohodek, priložnosti za podjetništvo.

Prednosti posameznih varovanih območij se med seboj razlikujejo in so predvsem odvisne od: osnovnih virov, narave lokalne/regionalne ekonomije, vodilnih struktur in stopnje angažiranosti ter vključenosti posameznikov.

Slika 1: Opredelitev vrednosti v območjih varovanja (Prilagojeno po Slabe Erker, 2005)

Figure 1: Definition of values in protected areas-economic aspect

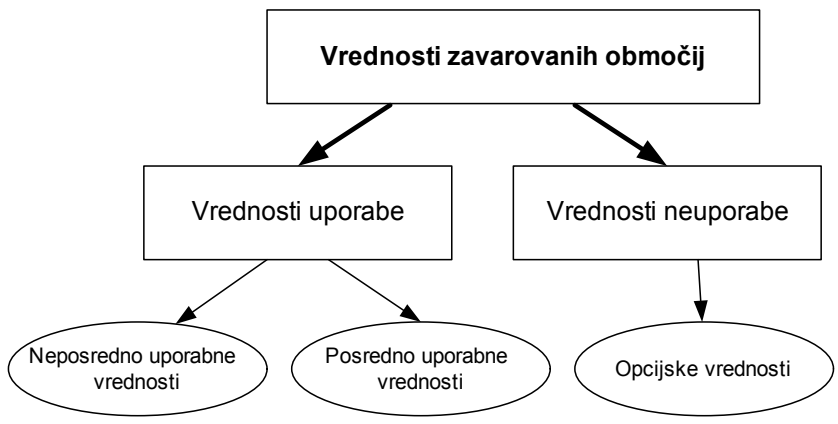


Gledano $\mathrm{z}$ vidika razvoja je ključnega pomena prepoznavanje številnih in heterogenih vrednosti območij varovanja, ki predstavljajo potencial posameznega območja. V kakšnem obsegu in na kakšen način pa bodo vsi potenciali uporabljeni, pa je seveda odvisno od različnih družbenih dejavnikov. Pomembno je tudi, da pri načrtovanju razvoja lahko z ekonomskega vidika argumentirano prikažemo vse potenciale in s tem utemeljimo trditev, da zavarovanje ne bi smelo biti ovira za razvoj (Slabe Erker, 2005).

Če želimo vrednosti obravnavati kot razvojne potenciale, jih moramo v prvi fazi vrednotiti kot uporabne vrednosti in vrednosti neuporabe. Uporabne vrednosti imajo lahko povsem neposredno ekonomsko vrednost, kot je npr. vrednost okoljskih potencialov (les, plodovi rastlin idr.), neposredna uporaba rastlin v medicini ali pa gre za neposredno trženje okoljskih in kulturnih potencialov (npr. trženje ohranjene biotske raznovrstnosti, bogate kulturne dediščine $\mathrm{v}$ turizmu). Uporabna vrednost je lahko tudi posredna. Izjemnega pomena v območjih varovanja je posredna vrednost ekosistemskih storitev (kroženje hranil, blaženje klimatskih sprememb idr.), vrednost kulturne dediščine, tako kulturne kot naravne vrednote pa imajo še izjemno izobraževalno, estetsko, slednje tudi rekreacijsko vrednost. Od vseh omenjenih posrednih uporabnih vrednosti je močno odvisno delovanje celotne družbe in gospodarstva.

Vrednosti neuporabe so neoprijemljive, imajo pa velik pomen za človekovo osebnost in kulturo. Govorimo o opcijskih in eksistenčnih vrednostih, ki imajo prav v zavarovanih območjih oziroma vseh območjih varovanja velik pomen. Samo zavarovanje določenega območja kaže na dejstvo, da gre za varovanje okoljskih ali kulturnih dobrin z visoko vrednostjo neuporabe, hkrati pa imajo pomembno vlogo v zavesti, kulturi in identiteti ljudi. Aktiviranje tega zavedanja pri ljudeh in kvalitativno dojemanje izjemnih naravnih in kulturnih dobrin ter prostora kot takega je ključno za drugačen pristop k ravnanju s prostorom in predvsem območji varovanja. Seveda imajo taka območja tudi številne uporabne vrednosti, ki bi jih bilo smiselno trajnostno koristiti, vendar so v zavarovanih območjih manj pomembne.

\section{OBMOČJA VAROVANJA V SLOVENIJI}

Slovenija se uvršča med geografsko najbolj raznolike države v Evropi. Izjemna ekosistemska mozaičnost se odraža predvsem v visokem deležu (35,5 \%) območij Natura 2000, še bolj pa v obsegu ekološko pomembnih območij, ki so zastopana na skoraj 50 \% slovenskega ozemlja. Evropsko povprečje obsega območij Nature 2000 predstavlja le okrog $17 \%$. Zavarovana območja v Sloveniji obsegajo $12 \%$ in kljub načrtom, da se bo ta delež do leta 2014 povečal na $20 \%$ (Nacionalni program varstva okolja, 2006) trenutno kaže, da bomo ta delež težko dosegli, kar pa lahko do neke mere pripišemo tudi obvezni opredelitvi območij Natura 2000 v letu 2004.

Zavarovana območja v Sloveniji delimo na širša in ožja. V prvo skupino sodijo narodni, regijski in krajinski parki, med ožja zavarovana območja pa se uvrščajo prostorsko manjša območja, ki navadno ciljno varujejo predvsem eno komponento in so strogi naravni in naravni rezervati ter naravni spomeniki. 
Slika 2: Zavarovana območja in območja Nature 2000 v Sloveniji

Figure 2: Protected areas and areas of Natura 2000 in Slovenia

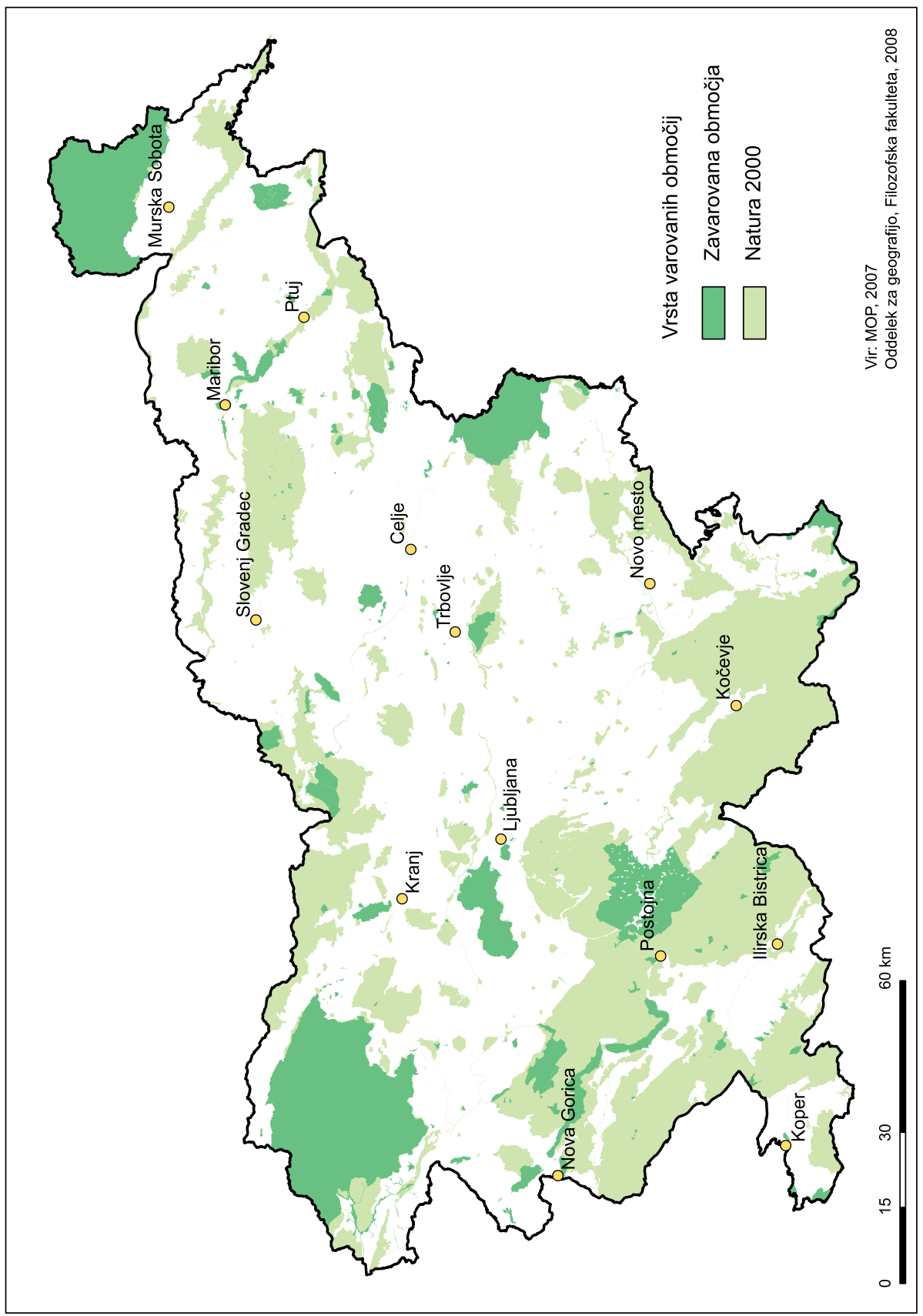


Preglednica 1: Zavarovana območja v Sloveniji po kategorijah mednarodnega združenja za varstvo narave (IUCN)

Table1: Protected areas in Slovenia according to the IUCN categories

\begin{tabular}{|l|c|c|c|}
\hline širša zavarovana območja & št. & obseg & \% državnega ozemlja \\
\hline narodni park & 1 & $838 \mathrm{~km}^{2}$ & 4,1 \\
\hline regijski park & 3 & $418 \mathrm{~km}^{2}$ & 2,1 \\
\hline krajinski park & 42 & $646 \mathrm{~km}^{2}$ & 5,0 \\
\hline ožja zavarovana območja & & & \\
\hline naravni rezervat & 52 & $62 \mathrm{~km}^{2}$ & 0,3 \\
\hline strogi naravni rezervat* & 1 & & \\
\hline naravni spomenik & 1217 & $124 \mathrm{~km}^{2}$ & 0,6 \\
\hline
\end{tabular}

Vir: Ministrstvo za okolje in prostor, 2008.

* nahaja se znotraj KP Kolpa

Po Zakonu o ohranjanju narave (Ur.l. R.S., 96/2004) sedanja širša zavarovana območja obsegajo približno $1900 \mathrm{~km}^{2}$ ali okrog $9 \%$ ozemlja Slovenije, vsa zavarovana območja skupaj pa 12,06 \%. Kulturno dediščino na tovrstnih območjih ureja Zakon o varstvu kulturne dediščine (Zakon o varstvu kulturne dediščine, Ur.l. R.S., 16/08). Svoj zakon ima Triglavski narodni park, ostala zavarovana območja pa so urejena z odloki. Delež zavarovanih območij Slovenijo uvršča na eno zadnjih mest, če deleže primerjamo z ostalimi državami Evropske unije (EU) (Berginc, 2006).

Leta 2004 je z vstopom v EU Slovenija določila posebna varstvena območja Natura 2000. Gre za ekološko pomembna območja, ki so na ozemlju EU pomembna za ohranitev ali doseganje ugodnega stanja vrst ptic (posebno območje varstva) in drugih živalskih ter rastlinskih vrst, njihovih habitatov in habitatnih tipov (posebno ohranitveno območje), katerih ohranjanje je v interesu EU. Namen omrežja Natura 2000 je dolgoročna ohranitev in povezovanje najvrednejših območij narave na nivoju Evrope z osnovnim ciljem - ohraniti biotsko raznovrstnost za bodoče rodove. Posebna varstvena območja so namenjena ohranjanju redkih in ogroženih živalskih in rastlinskih vrst ter njihovih življenjskih okolij (habitatov). Ker so redki ali na evropski ravni že ogroženi zaradi dejavnosti človeka to najpogosteje pomeni, da je na teh območjih treba vzdrževati ugodno stanje z različnimi ukrepi, bodisi zgolj nadaljevati z obstoječimi dejavnostmi, na primer s pašo ali košnjo suhih in vlažnih travnikov po cvetenju in gnezdenju, bodisi nekatere dejavnosti opuščati ali njihovo uvajanje preprečiti, npr. agromelioracije mokrišč. EU je to omrežje uvedla kot enega od mehanizmov za izvajanje direktive o ohranjanju naravnih habitatov ter prosto živečih živalskih in rastlinskih vrst (Direktiva sveta EGS 92/43) in direktive o ohranjanju prosto živečih ptic (Direktiva sveta EGS 79/409). Slovenija je sprejela sodelovanje v Naturi 2000 kot pridružitveno obveznost. Vse države članice so določile posebna ohranitvena območja in potrebne ohranitvene ukrepe. Članice morajo prav tako poskrbeti, da na teh območjih preprečijo slabšanje stanja naravnih habitatov in vrst. V Sloveniji smo leta 2004 določili območja Natura 2000 z Uredbo o posebnih varstvenih območjih (območjih Natura 2000). Opredeljenih je 286 območij, od tega jih 
je 260 določenih na podlagi direktive o habitatih (pSCI) (31,6 \%) in 26 na podlagi direktive o pticah (SPA) - 22,8 \%. Območja skupaj obsegajo slabih 36 \% površine Slovenije, večji del območij porašča gozd (71 \%), velik je delež brez vegetacije (pretežno stene), pomemben je tudi delež travišč. V zavarovanih območjih (Triglavskem narodnem parku, regijskih in krajinskih parkih ter rezervatih in naravnih spomenikih) je $25 \%$ skupne površine Natura 2000 območij. Območja se pretežno prekrivajo, saj je $60 \%$ površin, predlaganih na podlagi direktive o habitatih, znotraj predlaganih posebnih varstvenih območij po direktivi o pticah (Medmrežje 1).

Režim varovanja na območjih Natura 2000 je precej bolj ohlapen kot v zavarovanih območjih, saj nove dejavnosti in posegi v prostor niso vnaprej prepovedani, ampak je ustrezno naravovarstveno soglasje odvisno od načrtovanega projekta. Pomembno je, da se mreža območij Nature 2000 ohranja, kar pomeni, da bo tudi poseg, ki bi morebiti pomenil veliko škodo varovanim vrstam in habitatom, še vedno dovoljen, zlasti, če je v širšem javnem interesu. Zagotovljeno pa mora biti izboljšanje stanja istih vrst in habitatov na nekem drugem območju. Pri zavarovanih območjih se je potrebno v celoti držati režima varovanja, ki velja za posamezne zavarovane kategorije.

Poleg zavarovanih območij in območij Natura 2000 imamo v Sloveniji tudi ekološko pomembna območja 47,7 \%. To so tista območja habitatnih tipov, deli habitatnih tipov ali večje ekosistemske enote, ki pomembno prispevajo $\mathrm{k}$ ohranjanju biotske raznovrstnosti. Ekološko pomembna območja vključujejo:

- habitate prosto živečih rastlinskih in živalskih vrst ter habitatne tipe, katerih ohranjanje se izvaja na podlagi ratificiranih mednarodnih pogodb oziroma je njihovo ohranjanje $v$ interesu EU,

- $\quad$ habitatne tipe, ki so na ozemlju države redki, ranljivi, imajo majhno naravno območje razširjenosti ali predstavljajo za določeno biogeografsko regijo značilen habitatni tip,

- habitate rastlinskih in živalskih vrst, ki so na ozemlju Slovenije ogrožene zaradi izgube ali slabšanja kvalitet habitata.

\section{POTENCIALI ZA RAZVOJ ZAVAROVANIH OBMOČIJ IN OBMOČlJ NATURA 2000}

Zavarovana in varovana območja so v Sloveniji premalo poznana in cenjena - tako njihove vrste in obseg, varovalni režimi še posebej pa namen (za)varovanja. Pojav je v veliki meri posledica določanja tovrstnih območij v preteklosti. Prebivalstvo, ki živi znotraj zavarovanih območij ali v njihovi neposredni bližini, se zaradi omejitev pogosto počuti prikrajšano pri svojem delovanju in splošnem razvoju. Na drugi strani pa obiskovalci zavarovanih območij prepogosto ne upoštevajo režimov varovanja in mnogokrat niti ne poznajo razlogov varovanja (Lampič, Mrak, 2008).

Območja varovanja so prepoznana predvsem kot splošna razvojna ovira, kar so pokazale tudi raziskave Oddelka za geografijo, FF, Univerze v Ljubljani (2003 - 2007), ki smo jih izvedli v izbranih zavarovanih območjih: Naravni spomenik Dovžanova soteska, Krajinski park Lahinja, Krajinski park Goričko, Krajinski park Logarska dolina in Triglavski narodni 
park. Raziskava je zajela tako domačine kot obiskovalce, z njo pa smo ugotavljali njihov odnos do zavarovanih območij, razumevanje režimov varovanja, vzpostavljenost vrednot v zavarovanih območij ter prepoznavanje razvojnih priložnosti.

Obe skupini anketirancev, domačini in obiskovalci, so se strinjali z zavarovanjem območij, saj je po njihovem mnenju na ta način zagotovljeno ohranjanje naravnega okolja, ki ga prepoznavajo kot ključno vrednoto teh območij. Varovalne režime so označili kot prestroge in razvojno omejujoče, kljub temu pa so bili mnenja, da območja morajo ostati zavarovana in na nekaterih območjih (zlasti v Triglavskem narodnem parku) so v zavarovanju videli najboljšo razvojno priložnost. Tako se potrjuje uvodna misel, da zavarovanje območij v Sloveniji lokalne skupnosti prepoznavajo kot oviro in ne kot priložnosti za trajnostni razvoj.

Izkazalo se je, da se domačini pri razvoju zavarovanih območij večinoma odločajo za pasivno vlogo, le redki posamezniki so v razvoj že aktivno vključeni. Večja vključenost lokalnega prebivalstva je značilna za manjša zavarovana območja, pri tem pa je edinstveni primer Krajinski park Logarska dolina, kjer je v razvoj in upravljanje parka aktivno vključena večina domačinov. Takšno stanje je deloma posledica tradicije zavarovanja, saj je Logarska dolina eden naših najstarejših krajinskih parkov, hkrati pa gre v tem primeru za posrečeno kombinacijo naravnih razmer in ustreznega pozitivno naravnanega sodelovanja in organiziranja domačinov. Kot pozitivno pa ocenjujemo dejstvo, da se anketirani z zavarovanih območij večinoma ne nameravajo odseliti, saj visoko cenijo kvalitetno bivalno okolje.

Najbolj prepoznane vrednote varovanih območij spadajo v skupino okoljskih vrednot, in sicer je na prvem mestu mirno in čisto okolje, sledi ohranjena naravna pokrajina ter pestrost rastlinstva in živalstva (biotska raznovrstnost). Kulturna dediščina, tradicija in ohranjanje običajev so kot vrednote bolje prepoznani v krajinskih parkih, ki so prvenstveno namenjeni ohranjanju kulturne pokrajine in kulturne dediščine.

Območja varovanja v Sloveniji združujejo okoljske, kulturne, socialne in človeške vrednote in kot taka nudijo ugodne razmere za nadzorovan regionalni razvoj na osnovi dejavnosti, ki so v skladu predvsem s cilji ohranjanja naravne in kulturne dediščine in hkrati nudijo priložnosti za razvoj sonaravnih dejavnosti. Omenjene skupine vrednot z razvojnega vidika imenujemo »potenciali«, ki trenutno na naših območjih varovanja večinoma še nimajo bistvenih razvojnih funkcij.

Skupine okoljskih, kulturnih, socialnih in človeških potencialov združujejo različne vrednote, ki jih lahko zelo natančno definiramo na primarni ravni: npr. kot okoljski potencial varovanih območij so najpomembnejše naravne vrednote, ki so geološke, geomorfološke, hidrološke, botanične in zoološke. Naravnim vrednotam sledi biotska raznovrstnost (rastlinske in živalske vrste, habitatni tipi, ekosistemi, genski viri), naravni viri (voda, biomasa, les, zrak, prst, sončna energija, geotermalna energija, surovine), ekosistemske storitve (kroženje hranil, kisika, blaženje klimatskih sprememb, uravnavanje vodne bilance, nastajanje prsti, kontrola in zaščita pred erozijo, samočistilne zmogljivosti) ter zemljišče. Vsaka sestavina okoljskega potenciala ima lahko z razvojnega vidika neposredno uporabno vrednost (ekonomsko vrednost), posredno uporabno vrednost ali pa vrednost neuporabe, kar je odvisno od tipa varovanega območja in posledično od varovalnega režima.

Podobno velja tudi za ostale potenciale - kulturne, socialne in človeške. 
Preglednica 2: Razvojni potenciali (za)varovanih območij in njihove vrednosti uporabe in neuporabe

Table 2: Development potentials of protected areas and their possible use

\begin{tabular}{|c|c|c|c|}
\hline POTENCIAL & Sestavina potenciala & Podsestavina potenciala & Vrednosti \\
\hline \multirow{5}{*}{$\begin{array}{l}\text { OKOLJSKI } \\
\text { POTENCIAL }\end{array}$} & naravne vrednote & $\begin{array}{l}\text { geološke } \\
\text { geomorfološke } \\
\text { hidrološke } \\
\text { botanične } \\
\text { zoološke }\end{array}$ & PUV, VN \\
\hline & biotska raznovrstnost & $\begin{array}{l}\text { rastlinske in živalske vrste } \\
\text { habitatni tipi, ekosistemi } \\
\text { genski viri }\end{array}$ & PUV, VN \\
\hline & naravni viri & $\begin{array}{l}\text { voda } \\
\text { biomasa, les } \\
\text { zrak } \\
\text { prst } \\
\text { sončna energija } \\
\text { geotermalna energija } \\
\text { surovine }\end{array}$ & $\begin{array}{l}\text { NUV, PUV, VN } \\
\text { NUV } \\
\text { PUV } \\
\text { PUV } \\
\text { NUV, PUV } \\
\text { NUV } \\
\text { NUV }\end{array}$ \\
\hline & ekosistemske storitve & $\begin{array}{l}\text { kroženje hranil, kisika } \\
\text { blaženje klimatskih sprememb } \\
\text { uravnavanje vodne bilance } \\
\text { nastajanje prsti, kontrola in } \\
\text { zaščita pred erozijo } \\
\text { samočistilne zmogljivosti }\end{array}$ & PUV \\
\hline & zemljišče & & NUV, PUV, VN \\
\hline \multirow{4}{*}{$\begin{array}{l}\text { KULTURNI } \\
\text { POTENCIAL }\end{array}$} & $\begin{array}{l}\text { nepremična materialna } \\
\text { kulturna dediščina }\end{array}$ & $\begin{array}{l}\text { arheološka najdišča } \\
\text { naselbinska območja } \\
\text { stara mestna in vaška jedra } \\
\text { oblikovana narava in kulturna } \\
\text { pokrajina } \\
\text { stavbe, skupine stavb } \\
\text { umetnostne, zgodovinske ali } \\
\text { tehnične pričevalnosti }\end{array}$ & NUV, PUV, VN \\
\hline & $\begin{array}{l}\text { premična materialna } \\
\text { kulturna dediščina }\end{array}$ & $\begin{array}{l}\text { arhivsko in knjižnično gradivo } \\
\text { predmeti zgodovinskega, } \\
\text { umetnostno zgodovinskega, } \\
\text { arheološkega, etnološkega ali } \\
\text { naravoslovnega pomena }\end{array}$ & NUV, PUV, VN \\
\hline & živa dediščina & $\begin{array}{l}\text { običaji } \\
\text { znanje -živa mojstrovina }\end{array}$ & NUV, PUV, VN \\
\hline & kulturni potencial družbe & $\begin{array}{l}\text { jezik } \\
\text { tradicija } \\
\text { znanje } \\
\end{array}$ & $\begin{array}{l}\text { PUV, VN } \\
\text { PUV, VN } \\
\text { PUV, VN }\end{array}$ \\
\hline
\end{tabular}




\begin{tabular}{|c|c|c|c|}
\hline \multirow{4}{*}{$\begin{array}{l}\text { SOCIALNI } \\
\text { POTENCIAL }\end{array}$} & $\begin{array}{l}\text { vključenost prebivalstva } \\
\text { v javno življenje lokalne } \\
\text { skupnosti }\end{array}$ & $\begin{array}{l}\text { društva povezana z ohranjanjem } \\
\text { naravne in kulturne dediščine } \\
\text { društva, ki spodbujajo } \\
\text { sodelovanje, krepijo regionalni } \\
\text { razvoj }\end{array}$ & PUV, VN \\
\hline & $\begin{array}{l}\text { stopnja zaupanja in občutek } \\
\text { varnosti }\end{array}$ & $\begin{array}{l}\text { zaupanje v sodelovanje } \\
\text { zaupanje v vodstvene strukture } \\
\text { zaupanje v druge ljudi. } \\
\text { občutek varnosti }\end{array}$ & $\mathrm{VN}$ \\
\hline & $\begin{array}{l}\text { občutek pripadnosti } \\
\text { lokalnemu območju }\end{array}$ & & $\mathrm{VN}$ \\
\hline & $\begin{array}{l}\text { družinske, prijateljske } \\
\text { povezave in } \\
\text { medsosedske povezave }\end{array}$ & & $\mathrm{VN}$ \\
\hline $\begin{array}{l}\text { ČLOVEŠKI } \\
\text { POTENCIAL }\end{array}$ & $\begin{array}{l}\text { naravni prirastek } \\
\text { starostna sestava } \\
\text { spolna sestava } \\
\text { migracije } \\
\text { izobrazbena sestava } \\
\text { zaposlenost } \\
\text { poklicna sestava }\end{array}$ & & PUV \\
\hline
\end{tabular}

NUV - Neposredne uporabne vrednosti, PUV - Posredne uporabne vrednosti, VN-vrednosti neuporabe

Ustrezna opredelitev razvojnih potencialov je nujna za uresničevanje trajnostnega razvoja območij varovanja. Pomanjkanje upravljavskih načrtov in upravljanja zavarovanih območij (številna so brez upravljavske strukture) se odraža predvsem v neustreznem razvoju teh območij pa tudi sprejemanju varovanja med lokalnim prebivalstvom.

Glede na osnovni cilj varovanja posameznega območja smo opredelili ključne možnosti razvoja (preglednica 3). Rekreacija in turizem ponujata najprimernejšo razvojno možnost $\mathrm{v}$ vseh tipih varovanih območij. Izjema so le strogi naravni rezervati in naravni rezervati, kjer je ciljno varovanje/ohranjanje strogo omejeno in izjemnega pomena. Seveda pa je zelo pomembno, v kakšnem obsegu in oblikah se posamezne dejavnosti izvajajo v prostoru. Razvojne možnosti gre iskati predvsem v zelenem turizmu, rekreaciji, poudarjeni raziskovalni in izobraževalni vlogi območij in v sonaravnem kmetijstvu.

Zaradi pokrajinske in vrstne pestrosti bi moralo biti aktiviranje biotske raznovrstnosti kot ekonomske priložnosti prednostna razvojna naloga države, predvsem pa lokalnih skupnosti (občin, skupin občin) na območjih najvišje biotske raznovrstnosti (Hlad, Slabe Erker, 2004), torej na opredeljenih območjih Natura 2000 in ekološko pomembnih območjih.

Na tovrsten potencial kaže prikaz deleža območij Natura 2000 v slovenskih občinah, kjer velja izpostaviti predvsem tiste z več kot 75 \% ozemlja. Govorimo o lokalnih skupnostih, kjer je delež izjemnega naravnega okolja prevladujoč in bi veljalo razmišljati o aktiviranju razvoja, ki bo temeljil na ohranjanju lokalnih in regionalnih vrednot in jih istočasno tržil v 
smislu trajnostnega razvoja. Takšnih občin je kar 25 (12\% vseh), od tega kar 10 takšnih, ki so v celoti opredeljene kot območje Natura 2000. Tako je 7 občin z najvrednejšimi območji narave iz SV Slovenije (Goričko), Osilnica in Kostel sta iz skrajnega južnega dela Slovenije, Bistrica ob Sotli pa vzhodnega. Gledano z vidika aktiviranja potenciala biotske raznovrstnosti imajo največje možnosti občine južne in severozahodne Slovenije, občine vzhodne Slovenije (Kozjansko, Haloze) ter tiste na skrajnem severovzhodnem delu (Goričko). Prvi korak k usmerjanju razvoja nekaterih od naštetih območij je bil že narejen z zavarovanjem in skupnim upravljanjem širšega območja (npr. z ustanovitvijo Krajinskega parka Goričko), obsežna območja »zelenih« občin pa so še vedno prepuščena lastnim lokalnim pobudam (zadregam in nemoči), kar velja za velik del južne Slovenije, območje Haloz in pretežnega dela Pohorja.

Slika 3: Zastopanost območij Natura 2000 po občinah Slovenije - potencial za zavarovanje Figure 3: The percentage of Natura 2000 areas in Slovenian Municipalities - the potential for future protected areas

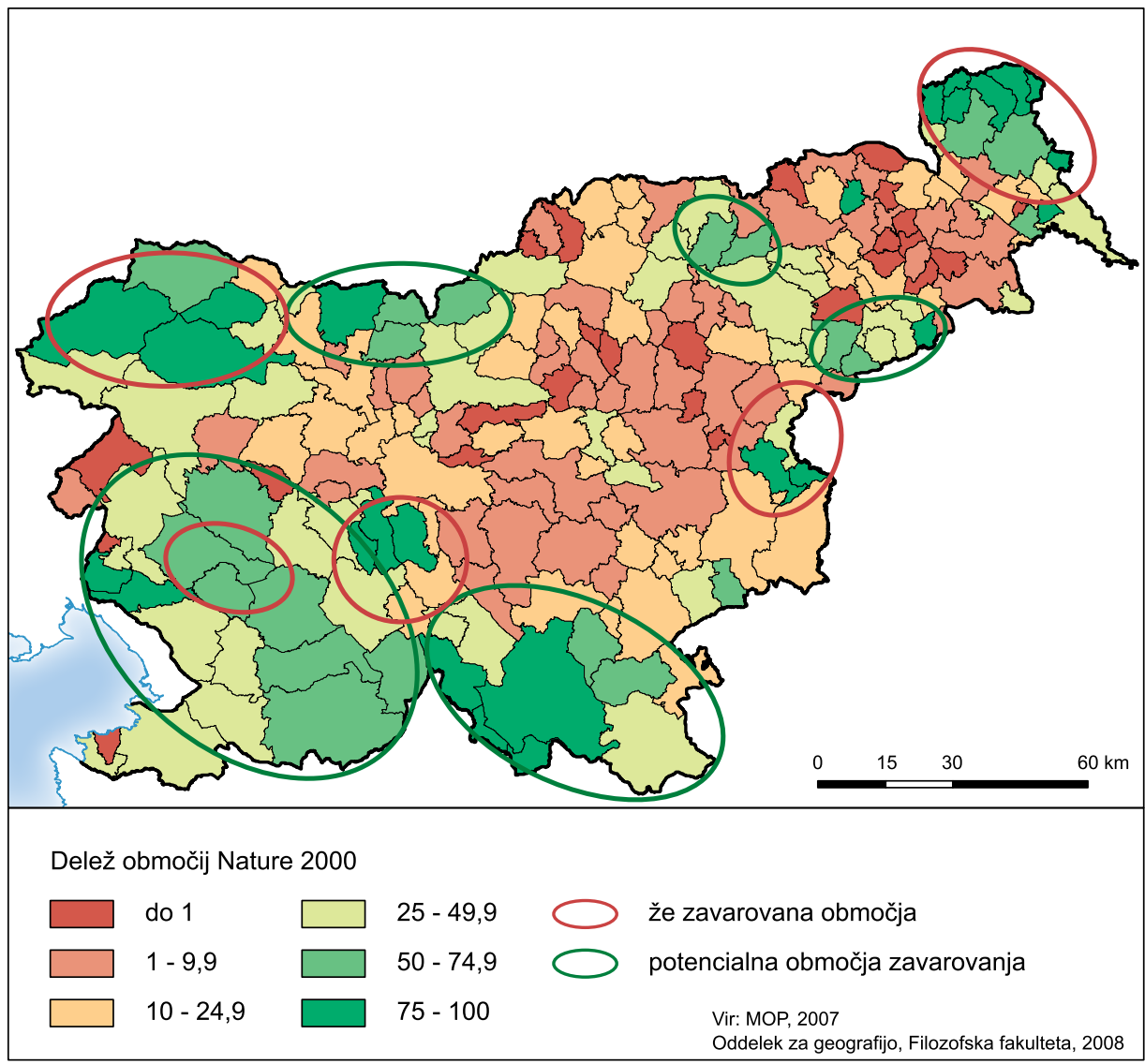


Preglednica 3: Možnosti razvoja v zavarovanih in varovanih območjih Slovenije Table 3: Development potentials in protected areas of Slovenia

\begin{tabular}{|c|c|c|c|c|c|c|c|c|c|c|}
\hline \multirow[b]{2}{*}{$\begin{array}{l}\text { Vrste zavarovanih in } \\
\text { varovanih območij }\end{array}$} & \multicolumn{3}{|c|}{$\begin{array}{l}\text { Varovanje in } \\
\text { ohranjanje }\end{array}$} & \multicolumn{7}{|c|}{ Možnosti razvoja } \\
\hline & 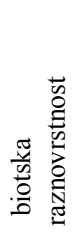 & 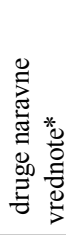 & 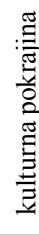 & $\begin{array}{l}\frac{0}{E} \\
\frac{0}{0} \\
\frac{0}{0} \\
\cdot \frac{\pi}{N} \\
\frac{\pi}{\pi}\end{array}$ & 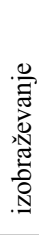 & 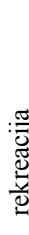 & 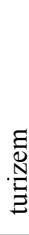 & 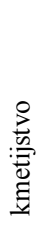 & 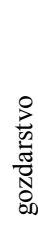 & 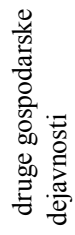 \\
\hline Narodni park & • & • & • & o & $\bullet$ & • & o & o & - & o \\
\hline Regijski park & $\mathrm{o}$ & o & $\bullet$ & o & $\mathrm{o}$ & • & • & • & o & o \\
\hline Krajinski park & o & o & $\bullet$ & o & $\mathrm{o}$ & • & - & - & o & $\mathrm{o}$ \\
\hline Naravni rezervat & - & o & o & • & • & 0 & o & - & - & - \\
\hline Strogi naravni rezervat & • & - & - & $\bullet$ & - & - & - & - & - & - \\
\hline Območja Nature 2000 & • & - & $\bullet$ & o & • & • & • & • & o & • \\
\hline $\begin{array}{l}\text { Ekološko pomembna } \\
\text { območja }\end{array}$ & • & - & $\bullet$ & o & $\mathrm{o}$ & • & • & • & o & - \\
\hline
\end{tabular}

- večje, o srednje, - manǰ̌e

* geološke, geomorfološke, hidrološke vrednote

\section{SKLEP - PRILOŽNOSTI ZA OBMOČJA VAROVANJA $\checkmark$ SLOVENIJI}

Velik delež varovanih območij, veliko število naravnih vrednot in velika biotska raznovrstnost so posledica geografske pestrosti Slovenije, dolgoletna prisotnost in dejavnosti človeka pa se odražajo v bogati kulturni dediščini in raznoliki kulturni pokrajini.

Zaradi gospodarskega razvoja in hitrih sprememb, ki se zadnja leta v okolju odražajo tako v urbaniziranih kot tudi podeželskih, perifernih območjih Slovenije, je bojazen o nadaljnji usodi sicer pregovorno bogatega naravnega in kulturnega slovenskega okolja/prostora upravičena in vse večja. Prav zaradi svoje izjemnosti imajo slovenska zavarovana in varovana območja na evropski ravni velik pomen, njihove dejanske vrednosti in »cene« pa sami žal pogosto ne znamo ovrednotiti in prepoznati.

Sistematičen prikaz glavnih razvojnih potencialov in opredelitev možnosti razvoja glede na tip območja varovanja predstavljajo osnovo za drugačno, razvojno razmišljanje pri načrtovanju dejavnosti in upravljanju območij varovanja. Zavarovana območja kot prostorska kategorija v praksi predstavljajo pogosto motnjo pri načrtovanju prostorskega razvoja na lokalni in regionalni ravni in nikakor niso prepoznana kot nova, trajnostna razvojna kategorija. Ta je še posebej značilna za območja Natura 2000, kjer izjemna biotska raznovrstnost evropskega pomena predstavlja edinstveno razvojno priložnost, ki pa je trenutno v celoti zanemarjena predvsem zaradi vsesplošnega slabega prepoznavanja namena območij Natura 
2000 ter nevzpostavljenega režima varovanja, ki velja za tovrstna območja. Z nadaljevanjem procesa ustanavljanja zavarovanih območij predvsem na območjih najvrednejših delov naravnega okolja (območja Natura 2000, Ekološko pomembna območja) v skladu z načrtom Nacionalnega programa varstva okolja bo mogoče jasno opredeliti tako cilje varovanja kot tudi ukrepe za njihovo doseganje ob sočasnem razvoju. Vendar je dolgoročna rešitev le v načrtnem in celovitem sistemu ustanavljanja novih zavarovanih območij, kjer že od samega začetka vključujemo vse deležnike (predvsem je pomembno vključevanje prebivalstva) in kjer se v procesu ustanavljanja že oblikuje tako upravljavski načrt kot določi upravljavec. Ustrezen upravljavski načrt, ki ima opredeljene ključne razvojne potenciale posameznega zavarovanega območja in tudi mehanizme za njihovo aktiviranje, hkrati pa je podvržen širšim merilom za vrednotenje uspešnosti izvajanja, je sistemska rešitev za obstoječa zavarovana območja in tista $\mathrm{v}$ ustanavljanju.

\section{Viri in literatura}

Berginc, M., 2006. Vloga države pri spodbujanju in omejevanju turističnega razvoja v zavarovanih območjih. Turizem v zavarovanih območjih. Turistična zveza Slovenije. Ljubljana. str. 5-9.

CURRY, P., 2006. Ecological Ethics: An Introduction. Polity Press.

Direktiva o ohranjanju naravnih habitatov ter prosto živečih živalskih in rastlinskih vrst. Direktiva sveta EGS 92/43.

Direktiva o ohranjanju prosto živečih ptic. Direktiva sveta EGS 79/409.

Gray, M., 2004. Geodiversity - valuing and conserving abiotic nature. Department of Geography, Queen Marry, University of London. London.

Hagett, P., 2001. Geography. A Global Synthesis. Prentice Hall.

Hlad, B., Slabe Erker R., 2004. Ekonomski razvoj in ohranjanje biotske raznovrstnosti. IB revija št. 4, Ljubljana. str. 52-66.

Kladnik, D., Ravbar, M., 2003. Členitev slovenskega podeželja. Geografija Slovenije 8, Geografski inštitut Antona Melika ZRC SAZU, Ljubljana.

Kirn, A., 2004. Narava-družba-ekološka zavest. Fakulteta za družbene vede. Ljubljana.

Lampič, B., Mrak, I., 2007. Nature conservation in Slovenia. Sustainable environmental research: promoting international cooperation and mutual assistance in natural parks. Olomouc. str. 26-34.

Lampič, B., Mrak, I., 2008. Prepoznavanje zavarovanih območij kot vrednote prostora. Geografija v šoli. XVII, št. 1. Ljubljana.

Medmrežje 1: http://www.natura2000.gov.si/. (citirano 5.11.2007)

Mikuš, T., 2006. Stanje in perspektive krajinskih parkov v Sloveniji. Magistrsko delo. Univerza v Ljubljani, Biotehniška fakulteta. Ljubljana.

Mrak, I., Potočnik Slavič, I., 2005. Living in a protected area. Adjusting to restrictions or development challenge?. Borders 3. International scientific conference Mountains without borders, 1. ed., Tarvisio - Villach - Kranjska gora, may 3rd-5th, 2004. Trieste. str. 83-91.

Ogorelec, B., 2005. Zakaj zavarovana območja potrebujejo interpretativne poti?. Gozd. vestnik, letn. 63, št. 3. Ljubljana. str. 153-156. 
Program upravljanja območij Natura 2000. 2007 - 2013, Operativni program. Ministrstvo za okolje in prostor. 2007.

Slabe Erker, R., 2005. Ekonomsko vrednotenje varovanja dediščine. Življenje v zavarovanih območjih. Zbornik. Ljubljana. str. $11-19$.

Šolar, M., 2001: Pregled nastajanja Triglavskega narodnega parka. 20 let zakona o Triglavskem narodnem parku, Zbornik. Bled. str. 105-106.

Uradni list RS št 96/2004. Zakon o ohranjanju narave (ZON-1).

Uradni list RS št. 16/2008. Zakon o varstvu kulturne dediščine (ZVKD-1).

Strategija gospodarskega razvoja Slovenije. UMAR. 2001.

\section{VALUABLES, VALUES AND DEVELOPMENT POTENTIALS OF PROTECTED AREAS}

\section{Summary}

High percentage of protected areas, high number of natural values and high level of biodiversity are the consequence of geographic variety of Slovenia as well as of the long term presence of human activities that reflect in rich cultural heritage and mosaic cultural landscape.

Due to economic development and rapid changes that are reflected in past years in the environment - in urban as well as in the rural, peripheral areas of Slovenia, the fear for the future destiny of rich nature and culture of Slovene environment/space is more then entitled and it is growing. The protected areas and areas of Natura 2000 in Slovenia are exceptional on the EU level and therefore they are of great importance but their actual economic value and "price" is usually not valued nor recognized.

The appropriate definition of development potentials is crucial for sustainable development implementation in protected areas. The lack of management plans and protected areas management (many of these areas have no management structures) especially reflects in the unsuitable development of these areas as well as in the acceptance of protection among the local population. Protected areas and areas of Natura 2000 in Slovenia are poorly recognized and valued - that holds for the extent of the protected areas, their types, protection regimes and especially the protection purposes. The phenomenon is mostly the consequence of past formation of protected areas. The inhabitants living in the areas or in the vicinity feel restricted in their lives and overall development due to protection. The systematic description of main development potentials and the definition of development possibilities according to the protection type represent the basis for different, development approach while planning the activities and management of the areas. In practice the protected areas as spatial category often represent an obstruction in planning the spatial development on local and regional level. They are mostly not recognized as new sustainable development category which is especially typical for the areas of Natura 2000 where the biodiversity of European importance represents the unique development opportunity. The latest is totally neglected due to overall poor knowledge on the purpose of Natura 2000 areas as well as the non existing protection 
regime for these areas. With the continuation of the establishment of new protected areas in the most valuable parts of natural environment (Natura 2000 areas, Areas of Ecological Importance) according to the plan in National program of environmental protection, the clear objectives will be defined as well as appropriate measures for their implementation with contemporary development. The long term solution is only in planned and integral system of establishment of new protected areas where from the very beginning all the stakeholders are involved (especially the local population). Second most important thing is the management plan and the defined future management institution that is known and planned also from the very beginning. The appropriate management plan should include well defined crucial development potentials of certain protected area and mechanisms for their activation but it should also be liable to wider measures for evaluation of implementation efficiency. Only this kind of management plan can be the systematic solution for the existing and future protected areas. 